\title{
Futures analysis
}

\author{
Tanja Hichert, ${ }^{1,2}$ Reinette Biggs ${ }^{2,3}$ and Alta de $\operatorname{Vos}^{4}$ \\ ${ }^{1}$ HICHERT AND ASSOCIATES, SOMERSET WEST, SOUTH AFRICA \\ ${ }^{2}$ CENTRE FOR SUSTAINABILITY TRANSITIONS, STELLENBOSCH UNIVERSITY, STELLENBOSCH, SOUTH AFRICA \\ ${ }^{3}$ STOCKHOLM RESILIENCE CENTRE, STOCKHOLM UNIVERSITY, STOCKHOLM, SWEDEN \\ ${ }^{4}$ DEPARTMENT OF ENVIRONMENTAL SCIENCE, RHODES UNIVERSITY, MAKHANDA, SOUTH AFRICA
}

\section{Key methods discussed in this chapter}

Scenarios and participatory scenario planning, futures wheels, three horizons framework, design/experiential futures, horizon scanning, Delphi, trend impact analysis, emerging issues analysis, causal layered analysis, appreciative inquiry, gaming (also known as 'gamification' or serious gaming), future workshops, visioning, back-casting, road-mapping

\section{Connections to other chapters}

Futures analysis methods enable the imagination and generation of alternative images of futures that are yet to exist. 'Utilising' and/or working with these alternatives, preferred and otherwise, and the signs that signal them, connects futures analysis very strongly to scenario development and participatory scenario planning (discussed in detail in Chapter 11). In this regard, futures analysis also connects to participatory modelling and planning (Chapter 13), serious games (Chapter 12) and facilitated dialogues (Chapter 9).

\section{Introduction}

Futures analysis methods can help people to think constructively and systematically about the future and advance our understanding of change and uncertainty in complex social-ecological systems (SES). This is important because there is not one single predictable future but multiple ones, depending on the complex, unpredictable interplays and interactions of actors, institutions, ecological processes and other elements of the system and its dynamics. Actively developing ideas, images and/or stories about different futures can enable us to make different choices and take different actions in the present in relation to, for example, risk mitigation, adaptation, resource allocation and strategy development, which can help build more sustainable and just futures.

Futures analysis methods are mostly derived from the field of futures studies - also commonly known as strategic foresight. While futures studies is established in academic arenas (see rossdawson.com/futurist/university-foresight-programs), it is not widespread 


\section{SUMMARY TABLE: FUTURES ANALYSIS}

\section{DISCIPLINARY BACKGROUND}

The methods in this chapter are derived from or have most commonly been used in:

Futures Studies. For quantitative forecasting: Mathematical Modelling, Simulation Modelling, Statistical Modelling, Operations Research

\section{KNOWLEDGE TYPE}

The methods in this chapter are primarily used to generate the following types of knowledge:

- Descriptive

- Exploratory

\begin{tabular}{|l}
\hline RESEARCH APPR \\
\hline The methods in this chapter \\
from or most commonly adopt \\
following research approach \\
- Analytical/objective \\
- Interpretive/subjective \\
- Collaborative/process
\end{tabular}

TEMPORAL DIMENSION

The methods in this chapter are most commonly applied to the following temporal dimensions:

- Present (typically within the last 5-10 years)

- Recent past (post-1700s)

- Future

\section{SPATIAL DIMENSION}

The methods in this chapter are primarily either or both:

- Non-spatial

- Explicitly spatial

The methods in this chapter are most commonly applied at the following spatial scales:

- Local

- Regional (provincial/state to continental)

- Global

- Multiple places/sites around the world

\section{PURPOSE OF METHOD}

The most common purposes of using the methods in this chapter are:

- System understanding

- Stakeholder engagement and co-production

- Policy/decision support

\section{SYSTEMIC FEATURES AND PROCESSES}

While most methods can do many things, the methods in this chapter are particularly good (i.e. go-to methods) for addressing the following:

- Social-ecological dependence and impact

- Power relations

- Social-ecological interactions over time

- Path dependency

- Transformation

- Social learning

- Exploring uncertainty 
or universally accepted as a field of research (Bengston, Kubik, and Bishop 2012). Key features of futures studies are:

- It deals with wicked (complex, interconnected) problems.

- It emphasises mutually assured diversity (MAD), meaning that foresight practitioners and participants should be conscious of having multiple identities and bring this to their work, e.g. being 'a scientific researcher', together with being 'a citizen of a particular country', together with being 'someone who holds a particular worldview', together with being 'a parent of young children'.

- It adopts a sceptical perspective that questions dominant axioms and assumptions.

- It is futureless in the sense that the results are mostly useful in the present (Sardar 2010, 177).

Futures studies generally emphasise the exploration of multiple futures to make sense of the present in order to better understand and potentially influence the future. Many futures analysis methods are well suited to SES work as futures studies generally adopt a systems approach and emphasise 'using' multiple futures to make sense of the present in order to better understand the future.

Three levels of futures studies can be identified: forecast, foresight and anticipation (Poli 2017). Forecast is the first level and is past oriented. It is quantitative and based on statistical calculations, such as time series regression, in which the past is extrapolated into the future. Forecasts are thus a product of probabilistic prediction based on the past dynamics of the system and have limited use when trying to understand complex, volatile and novel change.

The second level is foresight, which is future oriented. It works with the inherent ability of humans to imagine a future that does not exist, tell stories about it and thereby engage tacit knowledge to make assumptions explicit, and make sense of and prepare for what has yet to happen (Wilkinson 2017). Forecasting is often used in conjunction with foresight to provide an assessment of the most likely future - a baseline depicting a future which assumes that all other things remain equal.

Anticipation, as the third level of futures studies (not as in anticipatory systems, as it is sometimes used as a technical term - Poli 2017), is a present-oriented approach and consists of a 'forward-looking attitude' combined with the 'use' of that attitude that results in action (Poli 2017). In other words, anticipation focuses on understanding behavioural change based on an idea, or image, of the future. Anticipatory behaviour, or an anticipation capability, 'uses' the future in present-day decision-making processes. This behaviour is more robust than purely reactive behaviour. Strictly speaking, the future can only exist in the present as anticipation. 'Studying' the future - even though it does not exist - involves learning about and understanding how different ways of framing the future generate different perceptions of the present and hence alters preferences and choices.

Futures analysis methods (and tools) are applied differently from project to project and are nearly always highly customised. These methods are also constantly evolving. It therefore becomes important that the SES researcher knows why, and for what purpose, they want to incorporate futures analysis methods in their work. Is it to increase awareness of change? To create visions of a preferred future? To make sense of the present? Having a purpose for using futures analysis will ensure an appropriate choice of methods. Futures analysis methods can be used at any stage of an SES study, in conjunction with, and to augment, other SES analyses. 


\section{SES problems and questions}

Futures analysis methods are useful for helping to understand change. This includes understanding the patterns, systems and underlying driving forces that cause change to happen, making sense of the present, surfacing and challenging assumptions about the present and present worldviews, embracing uncertainty and pursuing alternatives rather than being 'locked' into forecasts.

For these reasons, SES research often turns to futures analysis methods to interpret, reiterate and recalibrate predictions made by more deterministic models and methods. Gao et al. (2016), for example, used scenario analysis to better understand deep uncertainty around outputs of land-use change models. Whereas scenario analysis (which is covered in Chapter 11) is probably the futures analysis method most used in this way, other futures analysis methods are also sometimes used. Strategic foresight is starting to become more popular in long-term conservation planning, for example (Cook et al. 2014).

Many futures analysis studies in the SES field concern questions of uncertainty and risk related to global change processes, particularly climate change (e.g. Bohensky et al. 2011), land-use change (e.g. Gao et al. 2016) and changes in socio-political and economic systems (e.g. Bohensky et al. 2011). In most cases, futures analysis is not merely used to identify elements of risk and uncertainty. Since many futures analyses are largely participative, they are also used to explore options for navigating risks and uncertainty, usually through coproduction of knowledge with key stakeholders.

The combination of participatory, narrative approaches and the ability of futures analysis to interact with more quantitative predictions make these methods particularly well suited to questions raised in the management and prioritisation of social-ecological landscapes, and for ultimately developing policies to manage these systems (Francis, Levin, and Harvey 2011). To name two examples: (a) scenario approaches and back-casting (Table 10.1) have been used to set conservation targets in social-ecological protected landscapes (Levin et al. 2015), and (b) visioning, scenarios and predictive forecasting are often combined to set realistic objectives and targets and to explore the consequences of potential management decisions on ecosystems under multiple potential scenarios of change (Francis, Levin, and Harvey 2011).

Futures analysis methods are used to understand not only what might be driving change in a system but also the cascading consequences of drivers of change, i.e. the many direct and indirect implications (Bengston 2016). Methods such as futures wheels and three horizons are well suited to exploring deeper drivers of change and possible future trajectories, which may be particularly relevant in resolving conflict and understanding management options in SES in flux. Case study 10.1 is an example of how futures analysis tools may be used in this way.

Futures analysis methods (especially Delphi and horizon scans) are sometimes used to understand the kind of questions relevant to SES research (e.g. Shackleton et al. 2011) and how research approaches that seek to understand SES (e.g. adaptive co-management, Plummer and Armitage 2007) might be changing and developing.

\section{Brief description of key methods}

Table 10.1 contains brief descriptions of some futures analysis methods that are useful for SES research, with references for further reading. The methods are categorised according to their main purpose: increasing awareness of change, exploring impacts of change, exploring alternative futures, exploring preferred futures, and informing strategies and action. 
Tanja Hichert et al.

Table 10.1 Summary of key methods used in futures analysis, categorised according to purpose

\begin{tabular}{|c|c|c|}
\hline Method & Description & References \\
\hline \multicolumn{3}{|c|}{ INCREASING AWARENESS OF CHANGE } \\
\hline Horizon scanning & $\begin{array}{l}\text { Horizon scanning focuses on identifying new and } \\
\text { emerging issues, typically called 'weak signals', as } \\
\text { well as existing trends. It can also serve as a future- } \\
\text { oriented sense-making exercise. Horizon scanning } \\
\text { entails a systematic information/intelligence } \\
\text { gathering and analysing activity. } \\
\text { Discussing the impacts of scanning output on an } \\
\text { issue is often conducted in a workshop format. } \\
\text { Output from a horizon-scanning exercise often } \\
\text { serves as input for scenarios, with the objective } \\
\text { of systematically looking for the 'driving forces' } \\
\text { that shape the future of the topic or issue being } \\
\text { examined. } \\
\text { Horizon scanning usually covers a wide range of } \\
\text { domains including social, technological, economic, } \\
\text { environmental and political domains. }\end{array}$ & $\begin{array}{l}\text { Key introductory texts } \\
\text { Hines et al. 2018; } \\
\text { UNDP } 2018 \\
\text { Applications to SES } \\
\text { Shackleton et al. 2011; } \\
\text { Bengston 2013; } \\
\text { Sutherland et al. } 2020\end{array}$ \\
\hline $\begin{array}{l}\text { Emerging issues } \\
\text { analysis }\end{array}$ & $\begin{array}{l}\text { Emerging issues analysis (EIA) is similar to horizon } \\
\text { scanning in that it seeks to identify initial sources of } \\
\text { change, usually by monitoring fringe thinking, niches } \\
\text { or outliers. Emerging issues are not mainstream } \\
\text { realities in the present, but could become emerging } \\
\text { patterns, major drivers or the source of a new trend. } \\
\text { It can be very effective to combine ElA with the three } \\
\text { horizons framework. }\end{array}$ & $\begin{array}{l}\text { Key introductory text } \\
\text { Molitor } 2003 \\
\text { Applications to SES } \\
\text { Bennett et al. } 2016 \\
\text { (although the activity of } \\
\text { searching for 'seeds of } \\
\text { a Good Anthropocene' } \\
\text { is not explicitly called } \\
\text { (crowdsourced) } \\
\text { emerging issues analysis, } \\
\text { it is essentially that, and } \\
\text { is an excellent example) }\end{array}$ \\
\hline Delphi & $\begin{array}{l}\text { The Delphi method is also often referred to as } \\
\text { 'expert panels', although a true Delphi specifically } \\
\text { involves iterative assessment of what selected } \\
\text { anonymous experts think future developments for a } \\
\text { given topic may be, and not just a random survey of } \\
\text { experts. Several rounds are conducted and experts } \\
\text { are allowed to alter their input after being exposed } \\
\text { to previous rounds. The aim is to clarify consensus. } \\
\text { A Delphi can be conducted either online or via } \\
\text { interviews. Specialised software is also available. }\end{array}$ & $\begin{array}{l}\text { Key introductory texts } \\
\text { Linstone and Turoff 1975; } \\
\text { Glenn and Gordon } 2004 \\
\text { Applications to SES } \\
\text { Plummer and Armitage } \\
2007\end{array}$ \\
\hline
\end{tabular}




\begin{tabular}{|c|c|}
\hline Method & Description \\
\hline \multirow[t]{2}{*}{$\begin{array}{l}\text { Trend impact } \\
\text { analysis }\end{array}$} & $\begin{array}{l}\text { Trend impact analysis (TIA) focuses on the potential } \\
\text { impacts and implications of trends and megatrends on } \\
\text { the topic or issue under consideration. Megatrends are } \\
\text { the great forces in societal and natural development that } \\
\text { are likely to affect the future in all areas over the next } \\
10-15 \text { years. A framework measuring likelihood, scale and } \\
\text { speed of arrival is often used. }\end{array}$ \\
\hline & $\begin{array}{l}\text { TIA ranges from highly sophisticated exercises, e.g. the } \\
\text { government of Singapore and World Economic Forum's } \\
\text { risk mapping, to brainstorming sessions about issues that } \\
\text { are very difficult to measure and track, such as the growth } \\
\text { in the popularity of veganism. }\end{array}$ \\
\hline
\end{tabular}

References

Key introductory text Glenn and Gordon 2004

Applications to SES Nair, Wen, and Ling 2014

\section{EXPLORING IMPACTS OF CHANGE}

Futures wheels Futures wheels is a group brainstorming method that explores and maps multiple levels of consequences of trends, events, emerging issues and/or future possible decisions. It is a graphic visualisation of direct and indirect, positive and negative future consequences of a particular change or development.
Key introductory text Glenn and Gordon 2004

Applications to SES Bengston 2016; Bengston, Dockry, and Shifley 2018; Pereira et al. 2018; Hichert, Biggs, and Preiser 2019

Three horizons framework
The three horizons framework is a conceptual model to aid people's thinking about current assumptions, emerging changes and possible and desired futures. It is a graphical approach developed to explore the change in importance of issues over time and connect the future to the present. It is an adaptable tool that is often used as an intuitive, accessible introduction to futures thinking and to make sense of emerging changes. At its most basic it is a systems model about the way things change over time. It is particularly good for working with complexity, developing future consciousness and recognising transformative change, while exploring how to manage transitions.
Key introductory texts Curry and Hodgson 2008;

h3uni.org/practices/ foresight-three-

horizons

Applications to SES Sharpe et al. 2016; Pereira et al. 2018; Hichert, Biggs, and Preiser 2019

\section{EXPLORING ALTERNATIVE FUTURES}

Design/ experiential futures
Experiential futures refer to a set of approaches to make alternative futures present and 'feel' real, i.e. the aim is to get people to experience the future. It is essentially a future brought to life materially or performatively, or both. It is all about engaging with futures using design (often prototyping), performance, film and materiality - objects and things - as well as media and modalities that have not traditionally been used.
Key introductory text Candy 2014

Applications to SES

Hichert, Biggs, and

Preiser 2019 
Tanja Hichert et al.

Table 10.1 (Continued)

\begin{tabular}{lll}
\hline Method & Description & References \\
\hline $\begin{array}{l}\text { Scenario } \\
\text { development }\end{array}$ & $\begin{array}{l}\text { Scenario development (see Chapter 11) is regarded as a } \\
\text { structured process (but it is useful to keep in mind that } \\
\text { there are many different approaches and processes for } \\
\text { creating scenarios (Bishop, Hines, and Collins 2007)) where } \\
\text { a group creates narratives or images of alternative futures of } \\
\text { an issue, and how those futures might unfold and affect the } \\
\text { issue. These stories are then used to inform decisions, plans } \\
\text { and policies with a view to improving them. }\end{array}$ & $\begin{array}{l}\text { Carpenter, Bennett, } \\
\text { and Peterson 2006 }\end{array}$ \\
\hline EXPLORING PREFERRE FUTURES
\end{tabular}

\begin{tabular}{|c|c|}
\hline $\begin{array}{l}\text { Appreciative } \\
\text { inquiry }\end{array}$ & $\begin{array}{l}\text { Appreciative inquiry originated in organisation } \\
\text { development. It is a large-group collaborative change } \\
\text { method structured as a set of iterative cyclical questions } \\
\text { that concentrate on the positive. The aim is to identify what } \\
\text { is working well, identify the energy for change and build } \\
\text { on that. The underlying assumption is that people are more } \\
\text { comfortable co-creating an unknown future if they can take } \\
\text { parts of today's successes forward and build upon them. }\end{array}$ \\
\hline
\end{tabular}

Future This is a three-day structured workshop process which
workshop originated in Europe in the early 1960s. The aim is to create visions of a preferred future. It starts off by analysing problems and challenges in the present, followed by brainstorming possible solutions. The best potential solutions are chosen democratically and are formulated into Key introductory text Bushe 2013

Applications to SES Van der Merwe, Biggs, and Preiser 2018 viable projects. The workshop ends with a plan of action.

\begin{tabular}{|c|c|c|}
\hline Visioning & $\begin{array}{l}\text { Visioning is any participatory activity or exercise designed } \\
\text { to come up with compelling visions/narratives/images of } \\
\text { preferred, often transformative, futures. These preferred } \\
\text { futures are always normative as opposed to possible } \\
\text { or plausible futures generated by scenarios. The aim is } \\
\text { to inspire, engage and enable people to act towards } \\
\text { creating a preferred future. }\end{array}$ & $\begin{array}{l}\text { Key introductory text } \\
\text { Ziegler } 1991 \\
\text { Applications to SES } \\
\text { Pereira et al. } 2018 \\
\text { Hamann et al. } 2020\end{array}$ \\
\hline $\begin{array}{l}\text { Causal layered } \\
\text { analysis }\end{array}$ & $\begin{array}{l}\text { Causal layered analysis is a four-level analysis examining } \\
\text { the litany ('headlines'), systems, worldviews and myths/ } \\
\text { metaphors associated with an issue. It is used to identify } \\
\text { different perspectives about the future and is good } \\
\text { for 'surfacing' underlying, sometimes sensitive issues. } \\
\text { Changing the deepest levels of myths/metaphors about } \\
\text { an issue is one way of developing preferred futures. }\end{array}$ & $\begin{array}{l}\text { Key introductory text } \\
\text { Inayatullah } 2008 \\
\text { Applications to SES } \\
\text { Heinonen et al. } 2017\end{array}$ \\
\hline \multicolumn{3}{|c|}{ INFORMING STRATEGIES AND ACTION } \\
\hline Road-mapping & $\begin{array}{l}\text { Road-mapping is a 'vision-into-action' technique which } \\
\text { is often used for technology planning to help turn ideas } \\
\text { into products or services. It maps potential pathways, with } \\
\text { timelines and actions, from the present to the preferred } \\
\text { future to help make it possible to reach that future. }\end{array}$ & $\begin{array}{l}\text { Key introductory texts } \\
\text { Garcia and Bray 1997; } \\
\text { Jackson } 2013 \\
\text { Applications to SES } \\
\text { No known example }\end{array}$ \\
\hline
\end{tabular}




\begin{tabular}{|c|c|c|}
\hline Method & Description & References \\
\hline Back-casting & $\begin{array}{l}\text { Much like road-mapping, back-casting works backward } \\
\text { from the preferred future to the present. It is a set of } \\
\text { imaginary steps detailing how a preferred future was } \\
\text { reached or brought about. These steps then form the basis } \\
\text { of actions to be taken, decisions and policies to be made, } \\
\text { and resources needed to create that preferred future. }\end{array}$ & $\begin{array}{l}\text { Key introductory text } \\
\text { Jackson } 2013 \\
\text { Applications to SES } \\
\text { Palomo et al. } 2011\end{array}$ \\
\hline $\begin{array}{l}\text { Gaming, } \\
\text { 'gamification' and/ } \\
\text { or serious games }\end{array}$ & $\begin{array}{l}\text { Gaming in futures-oriented activities - the terms } \\
\text { 'gamification' or serious games are also commonly } \\
\text { used - simulates real-world situations and } \\
\text { predicaments and engages participants by means } \\
\text { of, often goal-directed, play. It includes foresight } \\
\text { card decks, board games, immersive role-playing } \\
\text { experiences, futures labs and various types of online } \\
\text { games such as Foresight Engine. According to Bengston } \\
\text { (2016), an important rationale for the use of gaming } \\
\text { methods in futures research is that active learning } \\
\text { methods are often most effective. }\end{array}$ & $\begin{array}{l}\text { Key introductory text } \\
\text { Bengston } 2019 \\
\text { Applications to SES } \\
\text { Vervoort et al. } 2010\end{array}$ \\
\hline
\end{tabular}

\section{Limitations}

Because there is no set 'formula', other than quantitative forecasting, for when and how to use which futures analysis method, it can be difficult to successfully incorporate these methods into SES research as many of the methods require skilled facilitation. However, there is huge potential for adding value to SES research when employing these methods in collaboration with skilled future/foresight practitioners, which can then also lead to skills transfer.

None of the futures analysis methods aims to predict the future - something which is impossible. Despite the emphasis of horizon scanning and emerging issues analysis on detecting weak signals and early signs of change, neither of these methods is able to foresee tipping points or entirely novel events. They are, however, very useful in fostering greater awareness of, and learning about, sudden, surprising change, volatility and systemic turbulence. The methods are good for sense-making and sensitisation.

The outputs of some of the methods, especially the more creative ones, like causal layered analysis, or those working with outlier emerging issues, like emerging issues analysis, are often not regarded as authoritative and may suffer from a lack of credibility. Many of the methods are fairly new to the public sector, development sector and civil society, and people may be unfamiliar and uncomfortable with engaging in these processes. In contrast, many of these methods have either been developed in or used for many decades by the military and business sectors.

Futures analysis methods and the field of futures studies are actively evolving. In many instances, new developments are practitioner led, with the result that new methods are not well documented and knowledge about new developments can be quite fragmented. Fortunately, the field has several professional associations (such as the Association of Professional Futurists (apf.org), the World Futures Studies Federation (wfsf.org) and the US Public Sector Foresight Network (publicsectorforesight.org)) that share knowledge among members and make some of their publications available. Notable among these is the Foresight Competency Model and The Future of Futures e-book, both published by the Association of Professional Futurists. 


\section{Resource implications}

Many of the methods mentioned here require experienced, skilled facilitators with some background and knowledge of futures studies. With training, knowledge transfer and self-learning, however, the methods can be successfully applied by SES researchers themselves.

In general, and excluding potential future developments, no specialised hardware or software is necessary, although online curating tools such as Factr (factr.com), Pearltrees (pearltrees.com) and Pocket (getpocket.com) are very useful for organising feedstock for horizon scanning, trend impact analysis and emerging issues analysis. Scanning can be very time consuming - sifting signals from noise - and generates large amounts of surplus data. It is, therefore, advisable to devise a scanning system and obtain institutional support before committing to it. Doing a Delphi will require access to experts and it can be a very timeconsuming exercise for them.

All the methods are participatory, except when trend impact analysis and emerging issues analysis are conducted as single-researcher desk-based, or online crowdsourced, exercises.

\section{Case Study 10.1: Using futures analysis methods to generate visions of a 'Good Anthropocene'}

In November 2016, the Centre for Complex Systems in Transition (now the Centre for Sustainable Transitions) (CST) at Stellenbosch University, South Africa, wanted to 'solicit, explore, and develop a suite of alternative visions for "Good Anthropocenes" positive futures that are socially and ecologically desirable, just, and sustainable' (CSTGRAID 2017, 4). The project's aim was to create good stories about the future. The critical question for the project was: how can we imagine radically alternative positive futures for southern Africa arising from small-scale, experimental sustainability initiatives employing new ways of thinking or doing?

The first step could be regarded as a highly defined horizon-scanning process. Rather than throwing a wide net to identify emerging signals of change, scientists, researchers, sustainability practitioners and their networks compiled an initial database of 100 'seed' projects (goodanthopocenes.net), each catalogued and categorised. These are all small-scale, experimental projects and initiatives - new social institutions, technologies or frameworks for understanding the world - that are not yet mainstream. Examples include projects on urban gardening and renewable energy, as well as technological advances like gene therapy (Hamann et al. 2020).

The project team and 23 participants (split into four mixed groups) made up of a roughly equal mix of scientists, artists, social entrepreneurs and social/policy researchers created the visions of a 'Good Anthropocene' from the seeds in a three-day workshop. Each working group was responsible for building a positive scenario of the Good Anthropocene by combining three very different 'seeds' from the database: two southern African seeds and one technology 'wildcard' seed.

Participants first considered each of their three assigned seeds, one by one, and explored the impacts and implications of each. Futures wheels were used as the backbone of this exploration (Figure 10.1). To begin the impact mapping, each 
The participatory nature implies access to a suitable venue, often for a few days, and standard workshopping material (see Hichert, Biggs, and Preiser 2019). All the participative methods, but causal layered analysis in particular, benefit from participants with multiple cultural perspectives and different disciplinary backgrounds.

Engaging in futures and foresight work is often an exciting, inspiring and revelatory experience for participants (Pereira et al. 2018), so it is wise to allow enough time to do it properly.

\section{New directions}

Schultz (2012) suggests that new directions for futures analysis methods involve exploring humanity's inner spaces, such as fears, hopes and beliefs, psychological stance and cognitive bias with methods such as integral futures and verge (which draws on ethnographic futures concepts). Simultaneously there is 'a clear and welcome trend towards decentralised, massively distributed and inclusive futures work. Global computing and interconnected

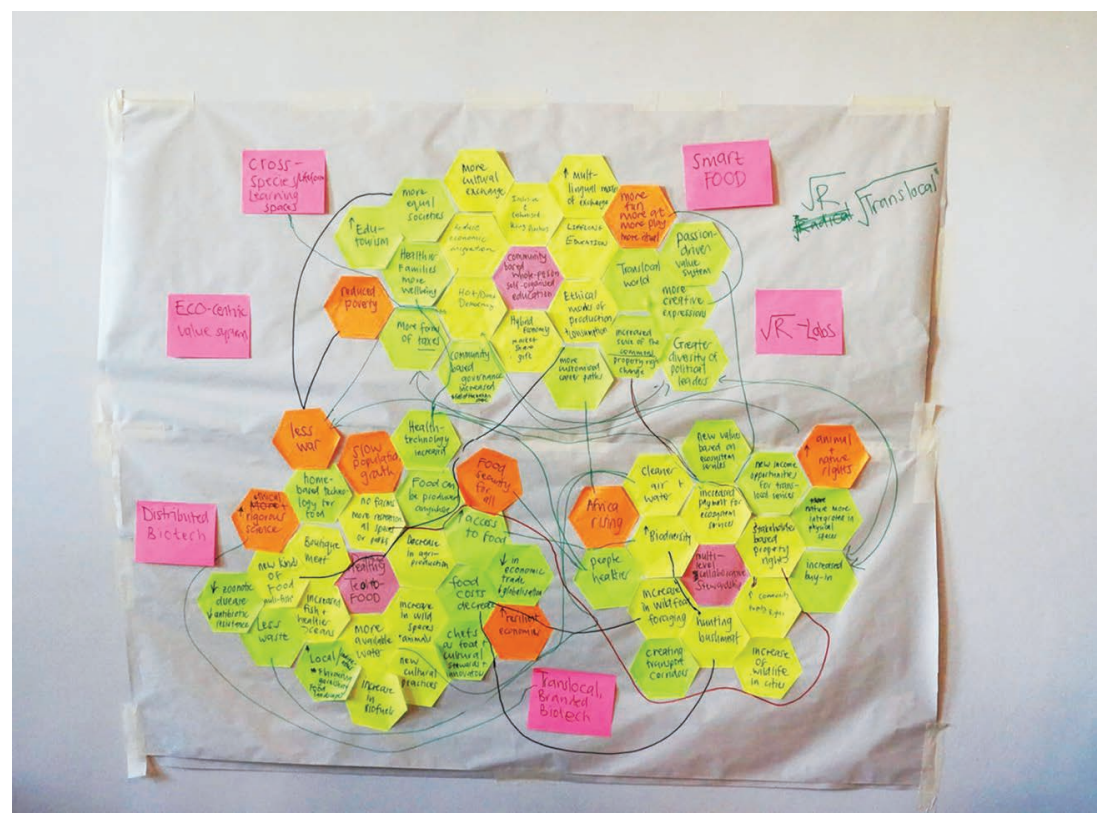

Figure 10.1 Three futures wheels placed in proximity to one another, together with cross-impact matrix cards, so that it is possible to conduct the influence mapping exercise (@) Gys Loubser)

seed was imagined in its future, mature form - as a mainstream 'new normal' rather than a fringe activity. Participants then mapped the primary, secondary and tertiary impacts and consequences cascading out from each seed. To consider how the three seeds and their impacts would interconnect, the afternoon of Day 1 
was used to create cross-impact matrices to explore outcomes as each of the seeds affected the others. As a final step on the first day, each working group created an influence map connecting the interactions between seeds, their impacts and the sub-impacts. After standing back and getting a sense of the emerging story, each group presented their new scenario via an artistic image (any medium), three fictional statistics and a social commentary/news headline (CST-GRAID 2017; Hamann et al. 2020).

Day 2 focused on building out the visionary narratives from the previous day's work. The goal was 'bold, vivid, hopeful scenario narratives - Visions of a Good Anthropocene in southern Africa' (CST-GRAID 2017; Hamann et al. 2020). The fact that the 'seeds' at the heart of each vision are existing pilot projects and initiatives demonstrating ways in which humans might be able to live in a 'Good Anthropocene' adds local specificity and enhances the credibility of each story. Because seed representatives were workshop participants, the experiences of active change agents enriched the vision stories, in addition to those details added by the artists and the scientists.

Back-casting is the tool most often used to connect visionary statements of audacious goals to action in the present. CST chose to use the three horizons tool often chosen as a framing tool or to make sense of the changes emerging from scanning - for back-casting. Each group considered their vision's place on Horizon Three, and then connected it to the present of Horizon One by 'looking for, and talking about, systemic changes, amplifications, clashes and potential inflection points' (CST-GRAID 2017; Hamann et al. 2020) in the Horizon Two transition space that bridges to the vision on Horizon Three (Figure 10.2).

The final activity for the participants was to share their visions in a creative, expressive and immersive manner. This is where experiential futuring comes in. Participants were given complete freedom as to how to do this, and examples included role-playing, dance, visual art, objects and theatrical performance (Figure 10.3).

Everything that informed the choice of methodology resulted from conversations about picking tools to get really far away from the generic futures, the ambient futures embedded in the social context, popular media and regular academic literature. The project team wanted to push past these 'everyday', more common images of the future. They wanted to avoid so-called 'used futures' and develop positive transformative stories that felt fresh and local. This drove their choice of the tools and methods mentioned above, which resulted in inspiring output that maximises difference from current conditions.

communication support digital exploration of our possible futures with new levels of creativity, rigor and participation' (Schultz 2012, 7).

This involves the application of online ICT tools such as Futurescaper (futurescaper. com) and Sensemaker (cognitive-edge.com/sensemaker), and global foresight games such as Foresight Engine (iftf.org/what-we-do/foresight-tools/collaborative-forecasting-games/ foresight-engine). Evolving artificial intelligence and big data analytics will change futures analysis methods in fundamental ways going forward.

Also worth watching are new methods, such as the Mānoa mash-up, emanating from the non-Western world (Pereira et al. 2018; Hichert, Biggs, and Preiser 2019) as there is a shift 


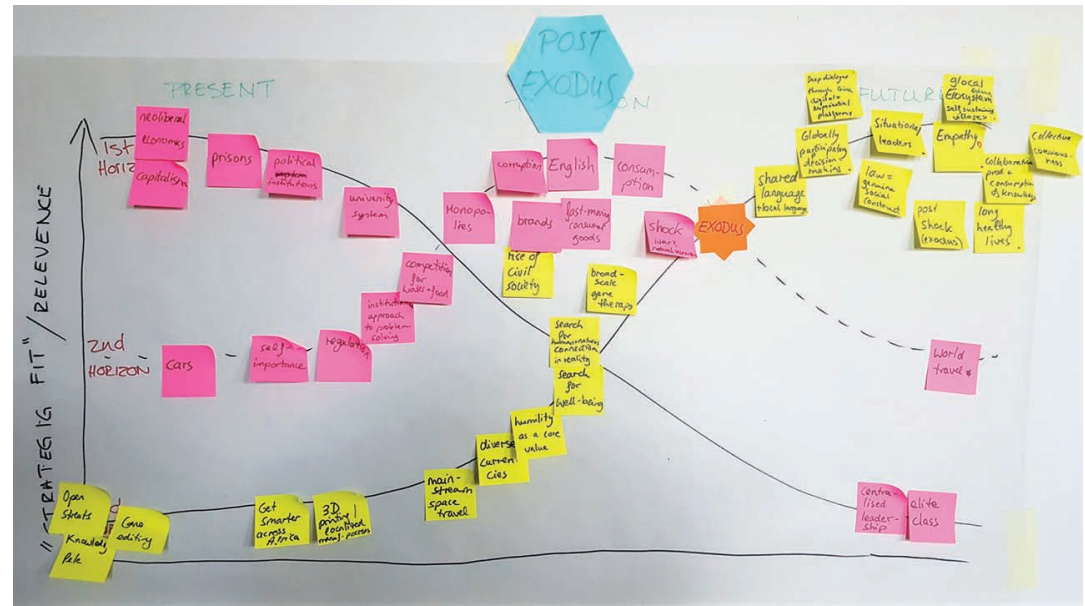

Figure 10.2 A populated three horizons framework (๔ Gys Loubser)

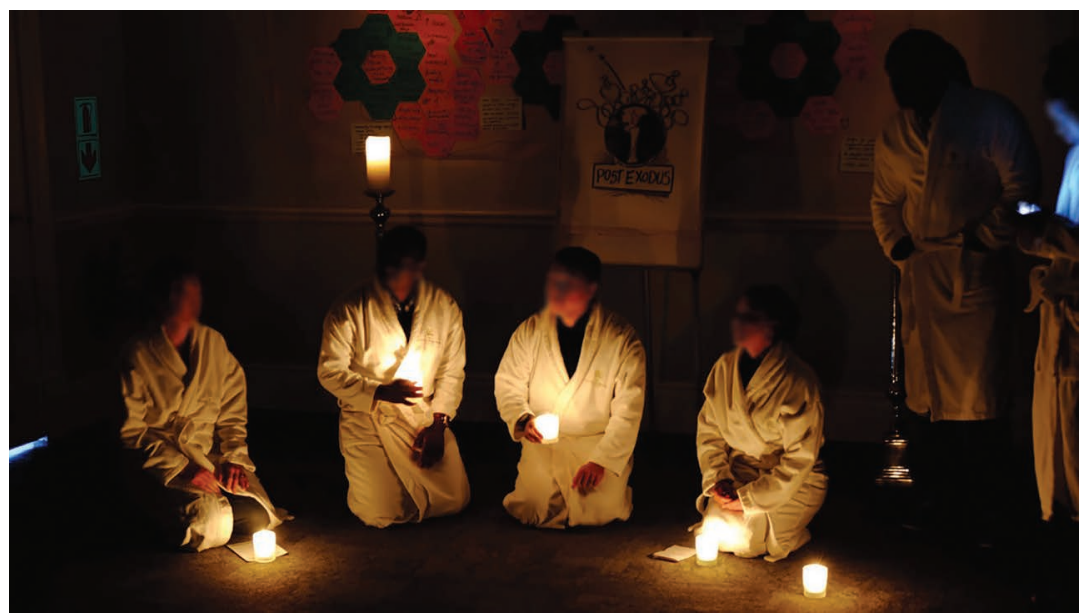

Figure 10.3 Sharing a vision of a future in an immersive, creative way (๑) Gys Loubser)

away from the formalisation of futures thinking in Europe and the USA to vibrant communities of practice, albeit small, in Asia and Africa.

In the afterword to The Future of Futures e-book, Curry $(2012,46)$ mentions some characteristics that will shape the future of futures thinking and foresight:

- More distributed and more networked, more at home with the social media tools

- More data

- Take a 'complexity turn': 'While the futures academy has already engaged with complex adaptive systems and emergence, these have been slower to inform futures methods.' 
- 'Rediscover some of its roots in philosophy, building (or re-building) a knowledge base that places more emphasis on how we know what we say we know when we make claims for futures work. The epistemology and ontology of futures work will become increasingly visible.'

- Different ways of knowing will become more evident in futures practice

- Become better informed about its history and its contexts

- Futures thinking was born into a world of growth, the emerging consumer economy and the Cold War. It will grow up in an age of 'descent' where futures addressing a world of resource shortage or even collapse will no longer be regarded as dystopian.

\section{Key readings}

Bengston, D.N. 2017. Ten Principles for Thinking about the Future: A Primer for Environmental Professionals. Gen. Tech. Rep. NRS-175. Newtown Square: US Department of Agriculture, Forest Service, Northern Research Station. www.fs.usda.gov/treesearch/pubs/55548.

Bengston, D.N. 2019. 'Futures Research Methods and Applications in Natural Resources.' Society and Natural Resources 32(10): 1099-1113. doi:10.1080/08941920.2018.1547852.

Bishop, P.C., and A. Hines. 2012. Teaching about the Future. London: Palgrave Macmillan.

Hichert, T., R. Biggs, and R. Preiser. 2019. Generating Visions of Good Anthropocenes: The Mānoa Mash-up Scenarios Methodology. CST Toolkit. University of Stellenbosch. www0.sun.ac.za/cst/publication/ generating-visions-of-good-anthropocenes-the-manoa-mash-up-scenarios-methodology.

UNDP Global Centre for Public Service Excellence. 2018. Foresight Manual: Empowered Futures for the 2030 Agenda.

\section{Acknowledgements}

This chapter benefited from the valuable insights, comments and contributions by David N. Bengston, PhD, environmental futurist and social scientist of the US Forest Service's Northern Research Station in St Paul, Minnesota. Thank you, David!

\section{References}

Bengston, D.N. 2013. Horizon Scanning for Environmental Foresight: A Review of Issues and Approaches. Gen. Tech. Rep. NRS-121. Newtown Square: US Department of Agriculture, Forest Service, Northern Research Station. doi:10.2737/NRS-GTR-121.

Bengston, D.N. 2016. 'The Futures Wheel: A Method for Exploring the Implications of SocialEcological Change.' Society and Natural Resources 29(3): 374-379.

Bengston, D.N. 2019. 'Futures Research Methods and Applications in Natural Resources.' Society and Natural Resources 32(10): 1099-1113. doi:10.1080/08941920.2018.1547852.

Bengston, D.N., M.J. Dockry, and S.R. Shifley. 2018. 'Anticipating Cascading Change in Land Use: Exploring the Implications of a Major Trend in US Northern Forests.' Land Use Policy 71: 222-229. www.fs.usda.gov/treesearch/pubs/55563.

Bengston, D.N., G.H. Kubik, and P.C. Bishop. 2012. 'Strengthening Environmental Foresight: Potential Contributions of Futures Research.' Ecology and Society 17(2): 10.

Bennett, E.M., M. Solan, R. Biggs, T. McPhearson, A.V. Norström, P. Olsson, L. Pereira et al. 2016. 'Bright Spots: Seeds of a Good Anthropocene.' Frontiers in Ecology and the Environment 14(8): 441-448.

Bishop, P., A. Hines, and T. Collins. 2007. 'The Current State of Scenario Development: An Overview of Techniques.' Foresight 9(1): 5-25. doi:10.1108/14636680710727516.

Bohensky, E., J.R. Butler, R. Costanza, I. Bohnet, A. Delisle, K. Fabricius, M. Gooch et al. 2011. 'Future Makers or Future Takers? A Scenario Analysis of Climate Change and the Great Barrier Reef.' Global Environmental Change 21(3): 876-893. 
Bushe, G.R. 2013. 'The Appreciative Inquiry Model.' In Encyclopedia of Management Theory, Volume 1, edited by E.H. Kessler, 41-44. Thousand Oaks: Sage.

Candy, S. 2014. 'Experiential Futures.' The Futurist 48(5): 34-37.

Carpenter, S.R., E.M. Bennett, and G.D. Peterson. 2006. 'Scenarios for Ecosystem Services: An Overview.' Ecology and Society 11(1): 29. http://ecologyandsociety.org/vol11/iss1/art29.

Cook, C.N., S. Inayatullah, M.A. Burgman, W.J. Sutherland, and B.A. Wintle. 2014. 'Strategic Foresight: How Planning for the Unpredictable Can Improve Environmental Decision-making.' Trends in Ecology and Evolution 29(9): 531-541.

CST-GR AID. 2017. Report on the Anthropocene Visioning Workshop, 15-18 November 2016, Cape Town, South Africa. GRAID Project Workshop. Centre for Complex Systems in Transition, Stellenbosch University, South Africa.

Curry, A., ed. 2012. The Future of Futures. Houston: Association of Professional Futurists.

Curry, A., and A. Hodgson. 2008. 'Seeing in Multiple Horizons: Connecting Futures to Strategy.' Journal of Futures Studies 13(1): 1-20.

Francis, T.B., P.S. Levin, and C.J. Harvey. 2011. 'The Perils and Promise of Futures Analysis in Marine Ecosystem-based Management.' Marine Policy 35(5): 675-681.

Gao, L., B.A. Bryan, M. Nolan, J.D. Connor, X. Song, and G. Zhao. 2016. 'Robust Global Sensitivity Analysis under Deep Uncertainty via Scenario Analysis.' Environmental Modelling and Software 76: 154-166.

Garcia, M.L., and O.H. Bray. 1997. Fundamentals of Technology Roadmapping. Albuquerque: Sandia National Laboratories.

Glenn, J.C., and T.J. Gordon, eds. 2004. Futures Research Methodology Version 3.0.

Hamann, M., R. Biggs, L. Pereira, R. Preiser, T. Hichert, R. Blanchard, H.W. Coetzee et al. 2020. 'Scenarios of Good Anthropocenes in Southern Africa.' Futures 118: 102526.

Heinonen, S., M. Minkkinen, J. Karjalainen, and S. Inayatullah. 2017. 'Testing Transformative Energy Scenarios Through Causal Layered Analysis Gaming.' Technological Forecasting and Social Change 124: 101-113.

Hichert, T., R. Biggs, and R. Preiser. 2019. Generating Visions of Good Anthropocenes: The Mānoa Mash-up Scenarios Methodology. CST Toolkit. University of Stellenbosch. www0.sun.ac.za/ cst/publication/generating-visions-of-good-anthropocenes-the-manoa-mash-up-scenariosmethodology.

Hines, A., D.N. Bengston, M.J. Dockry, and A. Cowart. 2018. 'Setting Up a Horizon Scanning System: A US Federal Agency Example.' World Futures Review 10(2): 136-151.

Inayatullah, S. 2008. 'Six Pillars: Futures Thinking for Transforming.' Foresight 10(1): 4-21.

Jackson, M. 2013. Practical Foresight Guide Chapter 3 - Methods. www.shapingtomorrow. com/ media-centre/pf-ch03.pdf.

Jungk, R., and N. Mullert. 1987. Future Workshops: How to Create Desirable Futures. London: Institute for Social Inventions.

Levin, P.S., G.D. Williams, A. Rehr, K.C. Norman, and C.J. Harvey. 2015. 'Developing Conservation Targets in Social-Ecological Systems.' Ecology and Society 20(4): 6.

Linstone, H.A., and M. Turoff. 1975. The Delphi Method: Techniques and Applications. https://web. njit.edu/ turoff/pubs/delphibook/delphibook.pdf.

Molitor, G. 2003. The Power to Change the World: The Art of Forecasting. Potomac: Public Policy Forecasting.

Nair, S., W.K. Wen, and C.M. Ling. 2014. 'Bangkok Flood Risk Management: Application of Foresight Methodology for Scenario and Policy Development.' Journal of Futures Studies 19(2): $87-112$.

Palomo, I., B. Martín-López, C. López-Santiago, and C. Montes. 2011. 'Participatory Scenario Planning for Protected Areas Management under the Ecosystem Services Framework: The Doñana Social-Ecological System in Southwestern Spain.' Ecology and Society 16(1): 23.

Pereira, L., T. Hichert, M. Hamann, R. Preiser, and R. Biggs. 2018. 'Using Futures Methods to Create Transformative Spaces: Visions of a Good Anthropocene in Southern Africa.' Ecology and Society 23(1): 19.

Plummer, R., and D.R. Armitage. 2007. 'Charting the New Territory of Adaptive Co-management: A Delphi Study.' Ecology and Society 12(2): 10. www.ecologyandsociety.org/vol12/iss2/art10.

Poli, R. 2017. Introduction to Anticipation Studies. Dordrecht: Springer. 
Sardar, Z. 2010. 'The Namesake: Futures; Futures Studies; Futurology; Futuristic; Foresight - What's in a Name?' Futures 42(3): 177-184.

Schultz, W. 2012. 'The History of Futures.' In The Future of Futures, edited by A. Curry. Houston: Association of Professional Futurists.

Shackleton, C.M., B.J. Scholes, C. Vogel, R. Wynberg, T. Abrahamse, S.E. Shackleton, F. Ellery, and J. Gambiza. 2011. 'The Next Decade of Environmental Science in South Africa: A Horizon Scan.' South African Geographical Journal 93(1): 1-14.

Sharpe, B., A. Hodgson, G. Leicester, A. Lyon, and I. Fazey. 2016. 'Three Horizons: A Pathways Practice for Transformation.' Ecology and Society 21(2): 47.

Sutherland, W.J., M.P. Dias, L.V. Dicks, H. Doran, A.C. Entwistle, E. Fleishman, D.W. Gibbons et al. 2020. 'A Horizon Scan of Emerging Global Biological Conservation Issues for 2020.' Trends in Ecology \& Evolution 35(1): 81-90.

UNDP Global Centre for Public Service Excellence. 2018. Foresight Manual: Empowered Futures for the 2030 Agenda.

Van der Merwe, S.E., R. Biggs, and R. Preiser. 2018. 'Building Social Resilience in Socio-Technical Systems through a Participatory and Formative Resilience Assessment Approach.' Systemic Change Journal 1(1): 1-34.

Vervoort, J.M., K. Kok, R. van Lammeren, and T. Veldkamp. 2010. 'Stepping into Futures: Exploring the Potential of Interactive Media for Participatory Scenarios on Social-Ecological Systems.' Futures 42(6): 604-616.

Wack, P. 1985. 'Scenarios: Uncharted Waters Ahead' and 'Scenarios: Shooting the Rapids.' Harvard Business Review, September-October and November-December.

Wilkinson, A. 2017. Strategic Foresight Primer. European Political Strategy Centre.

Ziegler, W. 1991. 'Envisioning the Future.' Futures 23(5): 516-527. 